\title{
Prevalence of Keloid among Female Students with Multiple Ears Piercing in the University of Port Harcourt, Nigeria
}

\author{
Peter D. Okoh ${ }^{1 *}$, Elekima W.A. Amachree ${ }^{2}$, John N. Paul ${ }^{2}$
}

\author{
${ }^{1}$ Department of Surgery, Faculty of Clinical Sciences, College of Health Sciences, University of Port Harcourt, Nigeria \\ ${ }^{2}$ Department of Anatomy, Faculty of Basic Medical Sciences, College of Health Sciences, University of Port Harcourt, Nigeria
}

*Corresponding author: Peter D. Okoh

Abstract

Background: The prevalence of keloid among adult female students with multiple ear piercing was determined in the University of Port Harcourt. Rivers State, Nigeria. Materials and Methods: A total number of 1000 participants comprising the age range of 20-30 years were used for this study. Questionnaires were given to the objects with multiple ear lobes piercing, from which the subjects with keloids were noted. Participants that had keloid were asked if they had any history of keloid in their family, when and how soon the keloid developed after piercing was done. Results and Discussion: It was noted that among the 1000 adult female students surveyed in University of Port Harcourt, about $99.5 \%$ of them with multiple ear lobe piercing had no keloid. Whereas $0.5 \%$ were found to develop keloid secondary to ear lobe piercing. Among the $0.5 \%$ of adult female students with keloid, only $0.1 \%$ had history of keloid in their family. This result appeared to be lower than previous reports on the prevalence of keloids in Africa. Comparing the keloid prevalence in African population with the Asian population showed that Taiwan had an annual keloid incidence rate 0.15 $\%$, while for the Europeans $0.1 \%$. Both values are far lower than the prevalence for African populations. Conclusion: This result shows that the prevalence of keloid secondary to ear lobe piercing is not common in the University of Port Harcourt. Rivers State Nigeria compared to what is obtainable in Africa, although higher than the values for Caucasians. Keywords: Prevalence, Keloid, earlobe, piercing.

Copyright @ 2020: This is an open-access article distributed under the terms of the Creative Commons Attribution license which permits unrestricted use, distribution, and reproduction in any medium for non-commercial use (NonCommercial, or CC-BY-NC) provided the original author and source are credited

\section{INTRODUCTION}

Keloids result from abnormal wound healing in response to skin trauma or inflammation. Keloid development rests on genetic and environmental factors [1]. It does not resolve spontaneously but may be flattened by applied pressure or with injection of potent corticosteroids alone or combine with surgical removal or debulking [2]. Keloid can develop in any part of the body that abrasion has occurred. Both genetic and environmental factors play a role in keloid development. Predisposed individuals may develop a keloid following any level of skin trauma including surgery, piercings, acne, tattooing, insect bites, burns, lacerations, abrasions, vaccinations, and any other process resulting in cutaneous inflammation [3-5]. They are more common in some sites such as central chest, the back, foot, the face and especially the ear lobe are common sites of keloid. Generally speaking, keloids are prevalent in black population [6-8].

Keloids can be defined macroscopically as large permanent scars that extend beyond the margin of the original injury. Unlike hypertrophic scars which are confined to the wound margins. Keloids tend to grow while hypertrophic scars often regress with time [9]. Histologically keloids are characterized by excessive collagen and extra cellular matrix deposition. Although the epidermis and papillary dermis are generally unaffected [10]. Deep in the dermis are thick, tightly packed collagen fibres randomly oriented in irregular sheets. The collagen is brightly eosinophilic. Generally, an inflammatory response is sparse. In the treatment or management of keloid, radiation treatment may reduce scar formation [11]. 


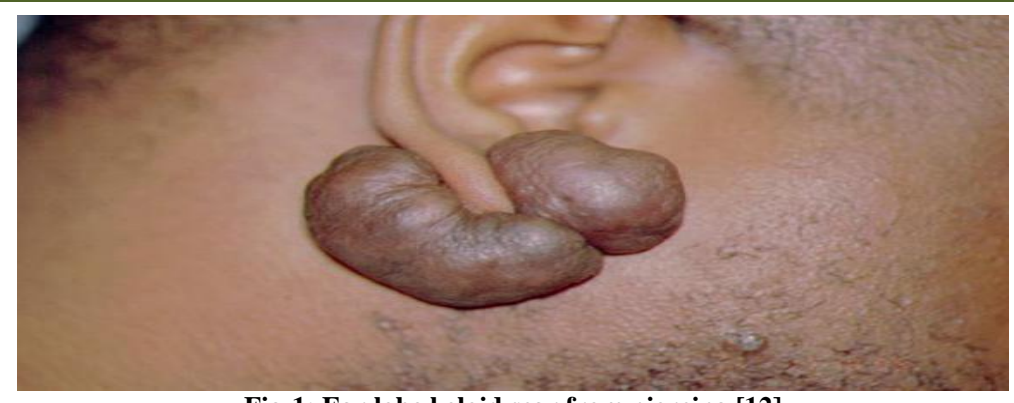

Fig-1: Ear lobe keloid scar from piercing [12]

Amongst the indigenous works done on keloids, Belie et al. [21] reported in his study on demographic and clinical characteristics of keloids in an urban center in Sub-Sahara Africa, that the prevalence of keloids resulting from piercing was $13.8 \%$. Currently, there are only few indigenous studies on keloids but a good number of works exist on Caucasians. Hence, this study was done to provide additional indigenous data for the prevalence of keloid.

However, some works have already been done by previous researchers in different populations. [13-23]

\section{AIM OF THE STUDY}

This study was carried out to determine the prevalence of keloids among female students with late multiple piercing of ear.

\section{MATERIALS AND METHODS}

This study was descriptive and cross-sectional. A survey of adult female with multiple piercing of ear was carried out. A convenient sample size of 1000 was chosen for this study and recruited purposively. A close ended questionnaire was used to collect the data. The participants with keloid due to multiple ear piercing were noted and asked questions on the period the piercing was done and how soon the keloid developed. They were also asked if they had history of keloid in their family, the method they employed to treat the Keloid growth and its effect, how many holes were pierced and how old they were when they pierced the holes. The age bracket of the participants was 20-30years with multiple ear piercing. Statistical analysis of the data collected was done using the descriptive statistical tool in SPSS version 21 . Ethical clearance was obtained from the University of Port Harcourt Research Ethics Committee before commencement of the study.

\section{RESULTS}

Table-1: Age distribution of participants

\begin{tabular}{|l|l|}
\hline Age (years) & Number of participants \\
\hline 20 & 25 \\
\hline 21 & 55 \\
\hline 22 & 255 \\
\hline 23 & 315 \\
\hline 24 & 75 \\
\hline 25 & 105 \\
\hline 26 & 125 \\
\hline 27 & 10 \\
\hline 28 & 20 \\
\hline 29 & 15 \\
\hline 30 & None \\
\hline
\end{tabular}

Table-2: Occurrence of keloid formation among the 1000 adult female students with multiple ear piercing

\begin{tabular}{|l|l|l|l|l|}
\hline $\begin{array}{l}\text { Age of students } \\
\text { (years) }\end{array}$ & $\begin{array}{l}\text { No of subjects } \\
\mathbf{n}(\boldsymbol{\%})\end{array}$ & $\begin{array}{l}\text { Age at which piercing } \\
\text { was done (years) }\end{array}$ & $\begin{array}{l}\text { No of holes } \\
\mathbf{n}(\boldsymbol{\%})\end{array}$ & $\begin{array}{l}\text { Keloid } \\
\text { formation }\end{array}$ \\
\hline 20 & $25(2.5)$ & 17 & $3(17.6)$ & 1 \\
\hline 21 & $55(5.5)$ & 19 & 0 & 0 \\
\hline 22 & $255(25.5)$ & 20 & $2(11.7)$ & 1 \\
\hline 23 & $315(31.5)$ & 23 & $3(17.6)$ & 1 \\
\hline 24 & $75(7.5)$ & 22 & $1(6.05)$ & 1 \\
\hline 25 & $105(10.5)$ & 21 & $2(11.7)$ & 0 \\
\hline 26 & $125(12.5)$ & 26 & $3(17.6)$ & 0 \\
\hline 27 & $10(1.0)$ & 26 & $2(11.7)$ & 0 \\
\hline 28 & $20(2.0)$ & 24 & $1(6.05)$ & 1 \\
\hline 29 & $15(1.5)$ & 28 & 0 & 0 \\
\hline 30 & None & - & - & - \\
\hline
\end{tabular}


Table-3: Age at which keloid formation was noted

\begin{tabular}{|l|l|l|}
\hline $\begin{array}{l}\text { Age of subjects } \\
\text { (years) }\end{array}$ & $\begin{array}{l}\text { Age keloid was } \\
\text { noted (years) }\end{array}$ & $\begin{array}{l}\text { Interval of } \\
\text { development }\end{array}$ \\
\hline 20 & 20 & 3 Months \\
\hline 21 & - & - \\
\hline 22 & 22 & 6 Months \\
\hline 23 & 23 & 8 Months \\
\hline 24 & 25 & 1 Year \\
\hline 25 & - & - \\
\hline 26 & - & - \\
\hline 27 & - & - \\
\hline 28 & 29 & 1 Year \\
\hline 29 & - & - \\
\hline 30 & - & - \\
\hline
\end{tabular}

In table 2 a total of 1000 adult female students with multiple ear piercing at the ages between 20-30 years were surveyed, 5 students had keloid

$$
\begin{gathered}
\text { Incidence }=\frac{\text { No of students with keloid }}{\text { Sample size }} \times 100 \\
\frac{5}{1000} \times 100=0.5 \%
\end{gathered}
$$

Therefore, the prevalence rate is $0.5 \%$.

\section{DISSCUSION}

The result of the study showed that $0.5 \%$ of the participants had keloid; only $0.1 \%$ had history of keloid in her family. The development of keloid in the participants with family history of keloid was faster as compared to those with no family history. This is to say that individuals with family history of keloid have a higher risk of developing keloid than those with no family history of keloid. This report is consistent the with previous reports of studies on keloid [2, 5, 6-8]. Belie et al. [21] did a study on demographic and clinical characteristics of keloids in an urban center in Sub-Sahara Africa and reported that the prevalence of keloids resulting from piercing was $13.8 \%$. Their result seems to be higher than the prevalence of keloid $(0.5 \%)$ in this current study. Comparing the keloid prevalence in African population with the Asian population showed that Taiwan had an annual keloid incidence rate $0.15 \%$ [22], while for the Europeans 0.1\% [23]. Both values are far lower than the prevalence for African populations.

The result indicates that the number of participants that developed keloids had at least one ear piercing (opening). Though, the familial (genetic) history of keloid is a well-known factor that causes keloid but there are other important factors that could cause keloid. These include; A deficiency or an excess of melanocyte hormone which decrease the percentage of mature collagen and increase soluble collagen. Trauma is often the precursor of Keloid. Previous reports have shown that the blacks have a greater chance of developing keloids than the whites. [8] Although, various treatment modality exists but none is consistently effective. The treatment includes, intralesional corticosteroid treatment, surgical excision, cryosurgery, laser surgery, radiation theory etc. Patients should note that reoccurring keloid typically grows larger than the original keloid [9-12]. Due to the trauma that occurs during the ear-piercing patents are advised to avoid piercing their ear lobe at late teenage and adulthood. Ear-piercing where necessary should be done at early childhood.

\section{CONCLUSION}

It was found that only $0.5 \%$ of the participants had keloid. Therefore, keloid development secondary to earlobe piercing is not common among adult female students in the University of Port Harcourt. Rivers State Nigeria.

\section{ACKNOWLEDGEMENTS}

We sincerely appreciate the entire management and staff of the Department of Surgery, Faculty of Clinical Sciences, College of Health Sciences, University of Port Harcourt, Nigeria and Department of Anatomy, University of Port Harcourt.

\section{Conflict of interest}

We write to state that there is no conflict of interest.

\section{Source of funding \\ Self-funding.}

\section{Author's contribution}

We write to state that all authors have contributed significantly and that all authors are in agreement with the contents of the manuscript. 'Author A' (Peter D. Okoh) designed the study and protocol, wrote the first draft of the manuscript; reviewed the design, protocol; 'Authors B' (Elekima W.A. Amachree) examined the intellectual content of the manuscript, 'Authors C' (John N. Paul) did the analysis of the study 
and literature search. All authors read and approved the final manuscript.

\section{REFERENCES}

1. Hahn AW, Resink TJ, Scott-Burden T, Powell J, Dohi Y, and Bühler FR. Stimulation of endothelin mRNA and secretion in rat vascular smooth muscle cells: a novel autocrine function. Cell Regul. 1990; 1(9):649-659.

2. Wang M, Chen L, Huang W, Jin M, Wang Q, Gao Z, Jin Z. Improving the anti-keloid outcomes through liposomes loading paclitaxel-cholesterol complexes. Int $\mathrm{J}$ Nanomedicine. 2019; $14: 1385-1400$

3. Asilian A, Darougheh A, Shariati F. New combination of triamcinolone, 5-Fluorouracil, and pulsed-dye laser for treatment of keloid and hypertrophic scars. Dermatol Surg. 2006; 32(7):907-15.

4. Lee JY; Yang CC; Chao SC; Wong TW. Histopathological differential diagnosis of keloid and hypertrophic scar. Am J Dermatopathol. 2004; 26(5):379-84.

5. Lu WS, Zheng XD, Yao XH, Zhang LF. Clinical and epidemiological analysis of keloids in Chinese patients. Arch Dermatol Res. 2015; 307 (2):109-14.

6. Park TH, Park JH, Tirgan MH, Halim AS, Chang $\mathrm{CH}$. Clinical implications of single- versus multiple-site keloid disorder: a retrospective study in an Asian population. Ann Plast Surg. 2015; 74 (2):248-51.

7. Andrews JP, Marttala J, Macarak E, Rosenbloom J, Uitto J. Keloids: The paradigm of skin fibrosis Pathomechanisms and treatment. Matrix Biol. 2016; 51:37-46

8. Kang S, Hur JK, Kim D. Advances in diagnostic methods for keloids and biomarker-targeted fluorescent probes. Analyst. 2019;144(6):1866-1875.

9. Verrecchia F, Mauviel A. Transforming growth factor-beta and fibrosis. World J Gastroenterol. 2007;13(22):3056-62.

10. Bux S, Madaree A. Involvement of upper torso stress amplification, tissue compression and distortion in the pathogenesis of keloids. Med Hypotheses. 2012; 78(3):356-63.

11. Chen Y, Chen Y, Liu Y. Abnormal Presentation of Aggressive Fibromatosis After Radiotherapy for Keloids: Case Report and Brief Literature Review. Ann Plast Surg. 2019; 83(1):104-107.
12. Touchi R, Ueda K, Kurokawa N, Tsuji M. Central regions of keloids are severely ischaemic. J Plast Reconstr Aesthet Surg. 2016; 69(2):e35-41.

13. Okuno R, Ito Y, Eid N, Otsuki Y, Kondo Y, Ueda K. Upregulation of autophagy and glycolysis markers in keloid hypoxic-zone fibroblasts: Morphological characteristics and implications. Histol Histopathol. 2018; 33(10):1075-1087.

14. Hayashi T, Furukawa H, Oyama A, Funayama E, Saito A, Murao N, Yamamoto Y. A new uniform protocol of combined corticosteroid injections and ointment application reduces recurrence rates after surgical keloid/hypertrophic scar excision. Dermatol Surg. 2012; 38(6):893-7.

15. Ogawa R, Akaishi S, Dohi T, Kuribayashi S, Miyashita T, Hyakusoku H. Analysis of the surgical treatments of 63 keloids on the cartilaginous part of the auricle: effectiveness of the core excision method. Plast Reconstr Surg. 2015; 135 (3):868-75.

16. De Cicco L, Vischioni B, Vavassori A, Gherardi F, Jereczek-Fossa BA, Lazzari R, Cattani F, Comi S, De Lorenzi F, Martella S, Orecchia R. Postoperative management of keloids: Low-dose-rate and high-dose-rate brachytherapy. Brachytherapy. 2014; 13(5):508-13.

17. Akaishi S, Koike S, Dohi T, Kobe K, Hyakusoku H, Ogawa R. Nd:YAG Laser Treatment of Keloids and Hypertrophic Scars. Eplasty. 2012; 12:e1.

18. Mourad B, Elfar N, Elsheikh S. Spray versus intralesional cryotherapy for keloids. J Dermatolog Treat. 2016; 27(3):264-269.

19. Lee YI, Kim J, Yang CE, Hong JW, Lee WJ, Lee JH. Combined Therapeutic Strategies for Keloid Treatment. Dermatol Surg. 2019; 45(6):802-810.

20. Coentro JQ, Pugliese E, Hanley G, Raghunath M, Zeugolis DI. Current and upcoming therapies to modulate skin scarring and fibrosis. Adv. Drug Deliv. Rev. 2019; 146:37-59.

21. Belie O, Ugburo A O, Mofikoya B O. Demographic and clinical characteristics of keloids in an urban center in Sub-Sahara Africa. Niger J Clin Pract. 2019; 22:1049-54.

22. Sun LM, Wang KH, Lee YC. Keloid incidence in Asian people and its comorbidity with other fibrosis-related diseases: a nationwide population-based study. Arch Dermatol Res. 2014; 306(9):803-8.

23. Young WG, Worsham MJ, Joseph CLM, Divine GW, Jones LRD. Incidence of Keloid and Risk Factors Following Head and Neck Surgery. JAMA Facial Plast Surg. 2014;16(5):379-380. 